\title{
Application of Think Pairs Share-Based on Learning Model to Increase Critical Thinking Skill
}

\author{
Yuli Widiyono $^{1}$, Joko Purwanto $^{2}$, Edi Sunjayanto ${ }^{3}$, Riawan Yudi Purwoko $^{4}$, Suyitno $^{5}$ \\ \{widiyono@umpwr.ac.id ${ }^{1}$ \}
}

Faculty of Teacher Training and Education, Universitas Muhammadiyah Purworejo, Indonesia ${ }^{1,2,3,4,5}$

\begin{abstract}
The objectives of the study is to achieve the learning process of speaking skills by developing a think pair share-based learning model, one of which is to improve the critical thinking skills of junior high school students. The design of this speaking model development is by adapting Borg and Gall's theory. They said in the theory of development of a Think Pair Share-based speaking learning model to improve the critical thinking of junior high school students. It is about learning language; how to speak, read and to respond correctly by developing a think pair share-based learning model. And the results of expert validation obtained the results and were categorized as valid. In terms of practicality, the model applied to the speaking learning process is in a good category. The result of the study states that it is raise to 3.19 . as the validator says in the final assessment which contains models it means valid. Based on the criteria of validity and practicality, the model developed is feasible to be used as an alternative to developing speaking learning to increase students' critical thinking skills so as to produce more focused speaking skills and produce quality thinking. Therefore Learning language must focus in what to say, think and react by experience, therefore the more error someone does, the more perfect someone perform.
\end{abstract}

Keywords: Speaking, think pairs share, critical thinking

\section{Introduction}

The think-pair-share learning model is a cooperative learning model that emphasizes student cooperation which consists of three stages, namely thinking, pairing, sharing [1]. Through think pair share students can develop social skills (pairing) and positive needs (sharing) so that it is expected to form a characterized educational process. In think-pair-share type, it gives students time to think and respond as well as help each other, so that student participation is more optimal [1]. In Think-pair-share learning, students provide opportunities for students to work individually or in groups to build self-confidence so that it will reduce and even eliminate the lack of self-confidence, discouragement, and fear that students often experience during learning [2].

Cooperative learning is learning that departs from constructivism theory. Cooperative learning is carried out by forming small groups whose members are heterogeneous to work in a team to solve problems or do something to achieve the goals to be achieved [3]. Cooperative learning is learning that consciously and deliberately creates loving interactions between students [4], [2]. They will of course need each other and work together to complete the assignment given by the teacher. Cooperative learning began to be introduced by Slavin. [1] explains, "in cooperative learning methods, students work together in four members teams to 
master material initially presented by the teacher. In the cooperative learning method, students sit together in groups of members to master the material presented by the teacher.

Cooperative learning is a learning activity in groups to work together to help one another, construct concepts, solve problems, or inquire. In cooperative learning, each group is built up of heterogeneous students (ability, gender, character), there are control and facilitation, and they ask for responsibility for group results in the form of reports or presentations. The basic principles behind cooperative learning, Group tasks are designed to be suitable for group work, positive interdependence is built in cooperation is necessary for students to succeed, attention and class time are given to interpersonal/cooperative skill building, participants learn together in small (2-5 member) groups, students are individually accountable for learning and participation, the instructors' role changes from being the "sage on the stage" to the "guide on the side [5].

The steps in cooperative learning are described by [6], namely, the teacher conveys goals and motivates students, presents information, organizes students into study groups, guides study groups, and works, evaluates, gives awards. Language skills have four components that must be mastered by students in learning languages, namely listening, speaking, reading, and writing. Speaking is a language skill that develops in a child's life, which is only followed by listening, and during that time the ability to speak or speak is learned. Talking is of course closely related to the development of vocabulary obtained by the child through listening and reading activities [7]. Brown said that role and function of languages are integrated with the subject of study. He claimed that language is used for communication devices, the language used speaking community [8].

The scholar argues that the purpose of speaking is to communicate. In order to convey something that the language user wants to communicate, he must be able to evaluate the effect of the communication on the listener and know the principles that underlie all conversation situations, both in general and individually [9]. Critical thinking skills are also needed in the learning process to speak. Krulik [10] argues that critical thinking includes thinking that tests, questions, connects, evaluates all aspects that exist in a situation or a problem. Students can also process some pictures, audio, or visual to think critically [11], [12], [13] the symbols of the social discourse [14]. For example, when someone is reading a script or listening to an expression or explanation, he tries to understand and tries to find or detect things some special and important things. The others said that there is a unique personal style and speech function in communication [15][16].

According to Desmita, [17] arguing that critical thinking is understanding some problems in depth, keeping the mind open to a variety of different approaches and perspectives, not simply trusting information that comes from various sources (oral or written), and think reflective and evaluative. Meanwhile, [18] critical thinking is actually a thought process that occurs in a person and aims to make reasonable decisions about something that can be believed to be true and what will be done later. By developing the Think Pair Share learning model, it is hoped that it can develop students' abilities in improving speaking skills, through stages and materials that are in accordance with the characteristics of students and the material being developed. Therefore, critical thinking also learn from the error in grammar, semantic and pronunciation [19]. 


\section{Method}

The research method in this study uses research and development developed by Borg and Gall [20][21]. The stages in the development of this model are adapted to ten steps of research and development. The subjects of this study were junior high school students in Purworejo. Data analysis used descriptive statistics by presenting the results of data analysis in the form of percentages and graphs of research results.

\section{Result and discussion}

Based on the results at the stage trial phase or this extensive trial was carried out to determine the ability of students to think critically in learning to speak with the TPS learning model. The results of the implementation show an increase compared to the previous stage.

From the validation results in general it is said that the learning model developed is in the good category with an average score of 3.19 and is suitable for use in teaching Indonesian spoken material. After the learning process can run according to the model developed, then an evaluation is carried out to measure learning achievement. Evaluation is carried out using tests, performance appraisal Data on the results of the competency assessment at the limited trial stage are presented in the Table 1.

Table 1. The results of learning speaking skills

\begin{tabular}{llll}
\hline Meeting & Cognitive & Psychomotor & Average \\
\hline I & 80 & 78 & 79 \\
\hline
\end{tabular}

On the results of practicality or implementation of learning with the TPS model to improve students' critical thinking skills at the limited trial stage presented in Table 2.

Table 2. TPS Model Implementation in Increasing Students' Critical Thinking Ability

\begin{tabular}{lll}
\hline No & \multicolumn{1}{c}{ Learning Activities } & Skor \\
\hline 1 & Introduction and motivation & 3 \\
2 & Phase Think & 2.5 \\
3 & Phase Pair & 2.7 \\
4 & Phase Share & 2.7 \\
5 & Evaluation & 3 \\
\hline \multicolumn{2}{c}{ Average } & 2.78 \\
\hline
\end{tabular}

From the results of the validators' assessment which contains content validation, and about models, the result is 3.19 or valid category. These components include: Suitability of material according to KI, The learning model is in accordance with the competence (urgency, continuity, and daily use), The learning model can be taught to students easily and is in accordance with its function, The learning model can make it easier to explain the concept of material, The learning model presented is clear and logical in accordance with the syntax, The use of language is in accordance with the rules of the Indonesian language, Use of unambiguous language, Do not use negative language or sentences, Compatibility of the instrument with the material, The evaluation includes indicators of achievement, Difficulty level on each instrument, The level of 
effectiveness of the instrument on speaking mastery. In the activity of measuring speaking skills, it was found that the average score was in a good category. The description of learning outcomes in applying the Think pair share model to improve critical thinking skills is presented in the Figure 1.

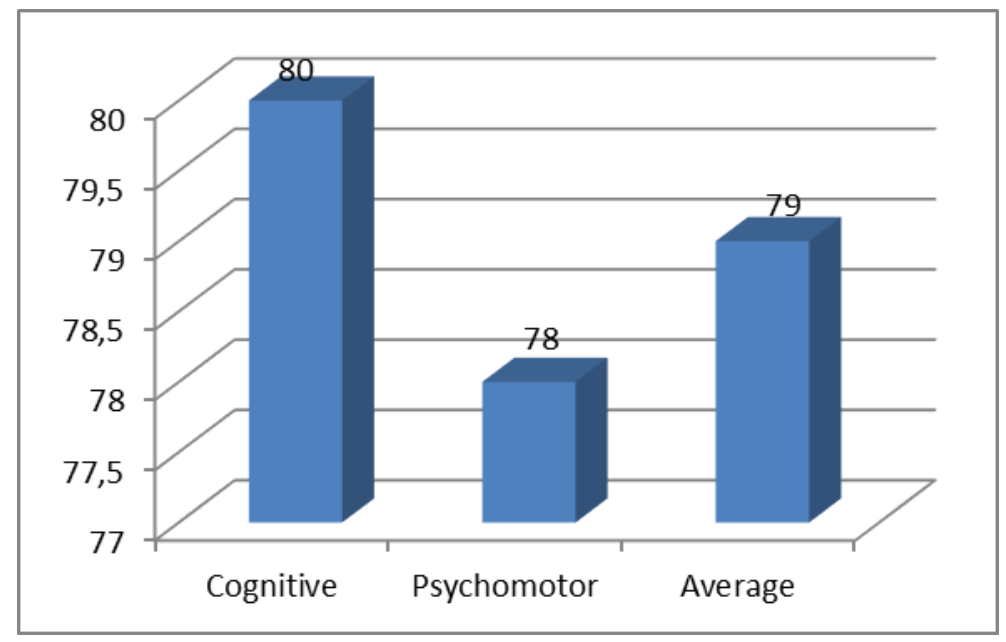

Fig. 1. Average results of speaking skills assessment at the broad trial stage

The results of practicality or implementation of learning with the TPS model to improve students' critical thinking skills at the broad trial stage presented in Figure 2.

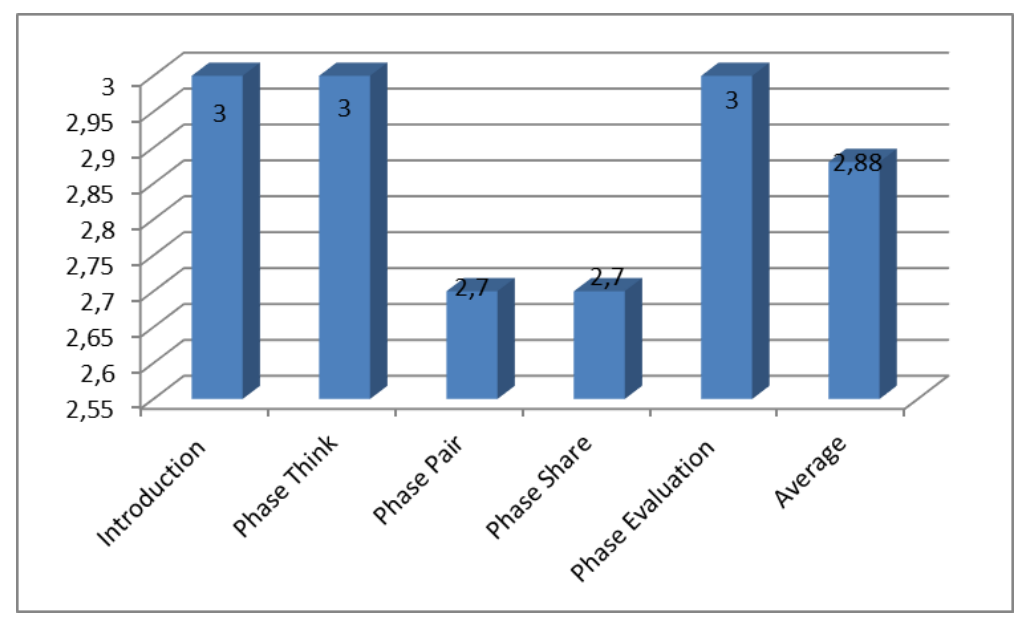

Fig. 2. The implementation of the TPS model in improving students' critical thinking skills

From the table and graph above, it is known that the practicality or feasibility of the TPS learning model in speaking skills to improve students' critical thinking skills is in a good category. 


\section{Conclusion}

Based on the results and discussion of research on the think pair share model to improve critical thinking skills, it can be concluded that cooperative learning is an interactive activity that will provide learners to form synergies that benefit all members. Communication between members will have an effect on the group. Communication skills are also a long process because every learner cannot be expected to become a reliable communicator immediately [5]. This process is a very beneficial process because it will foster the mental and emotional development of the students. Started with the implementation of the think pair share learning model, it is known that the practicality and responses of students in learning are interesting or good so that they can provide the motivation that has an impact on increasing students' critical thinking skills. Learning language must focus in what to say, think and react by experience, therefore the more error someone does, the more perfect someone perform [19].

\section{Acknowledgment}

We would like to express my big thanks to Allah Subhanahu Wa Ta'ala, The Almighty. We can finish our article soon. Our best friends in University, motivates and burns our spirit. My beloved friend as researchers who give us support financially also aided us in holding and focusing the research and we know so many new things we are thankful to them. Secondly, we would like to thank friends and participants who give much help to us in completing this project in the limited time.

\section{References}

[1] R. E. Slavin, Cooperative Learning: Theory, Reseach, and Practice. Boston: Allymand Bacon, 1995.

[2] Anita Lie, Cooperative Learning Mempraktikkan Cooperative Learning di Ruang-ruang Kelas. Jakarta: Grasindo, 2010.

[3] M. Ibrahim, Pembelajaran Kooperatif. Surabaya: Unesa, 2000.

[4] N. and Agus Gerrad S, Pembelajaran Konstektual (Contextual Teaching and Learning/CTL) dan Penerapannya dalam KBK. Malang: UMPress, 2003.

[5] A. Macpherson, Cooperative learning group activities for college courses a guide for instructors. Richmond: Kwantlen Polytechnic University, 2008.

[6] Suyatno, Menjelajah Pembelajaran Inovatif. Sidoarjo: Masmedia Buana Pustaka, 2009.

[7] H. G. Tarigan, Berbicara sebagai suatu keterampilan berbahasa. Bandung: Angkasa, 2008.

[8] H. D. Brown, Principles of language learning and teaching. 2007.

[9] M. G. A. dan. M. U.S, Kemampuan Berbicara Bahasa Indonesia. Jakarta: Erlangga, 1998.

[10] Krulik and Rudnick, Innovative Task to Improve Critical and Creative Thinking Skills. Reston, Virginia: Yearbook NTCM, 1999.

[11] J. M. O. Parapi, L. I. Maesaroh, Basuki, and E. S. Masykuri, "Virtual Education: A Brief Overview of Its Role in The Current Educational System," Scripta The English Department Journal, vol. 7, no. 1, pp. 8-11, 2020.

[12] E. S. Masykuri, "Operating Android by Tapping Google Map Apps to Learn Direction In Vocational School,” UNIVERSITAS MUHAMADIYAH PURWOREJO, vol. 1, no. 1, p. 112, Apr. 2013.

[13] S. Daru Santoso, E. Sunjayanto Masykuri, Y. Widiyono, and K. Sholeh, "Does Sony Vegas Platinum Pro 13 Help Students to Understand Pragmatic Well?," in International Seminar On Recent 
Language, Literature, And Local Culture Studies (BASA 2018, 2018, vol. 280, [Online]. Available: https://www.atlantis-press.com/proceedings/basa-18/25906104.

[14] R. Nurhadi and E. S. Masykuri, "Symbol Meaning and Dialectic Perspectives on Social Media," presented at the Proceedings of the 1st Borobudur International Symposium on Humanities, Economics and Social Sciences (BIS-HESS 2019), Magelang, Indonesia, May 2020, doi: https://doi.org/10.2991/assehr.k.200529.234.

[15] "Understanding Personal Intention by Elaborating Speech Function Using Social Media International Whatsapp Group."

[16] Mohammad Fakhrudin, E. S. Masykuri, K. Sholeh, and U. Faizah, "Analysis Varied Style of Conversation by Phone in Indonesian Teaching Learning," EAI, no. 5, Feb. 2020, doi: dx.doi.org/10.4108/eai.28-9-2019.2291063.

[17] Desmita, Psikologi Perkembangan. Bandung: PT Remaja Rosda Karya, 2006.

[18] R. H. Ennis, Critical Thinking. Upper Saddle River, New Jersey: Prentice Hall, Inc, 1996.

[19] T. Jampi, P. Dewi, and E. S. Masykuri, "The Grammatical Error Analysis Found in Students' Composition," Lensa: Kajian Kebahasaan, Kesusastraan, dan Budaya, vol. 10, no. 2, pp. 218-233, Dec. 2020.

[20] W. R. Borg and Gall, M. D., Educational Research An Introduction. London: Longman, 1983.

[21] M. Gall D., J. P. Gall, and W. R. Borg, Gall, M.D., Gall, J.P., Borg, W.R. (2007), Educational research: An introduction (8th ed.). Boston: Pearson., 8th ed. Boston: Pearson, 2007. 